\title{
Development of flax production in Ukraine
}

T. Pryimachuk, candidate of economics sciences

\section{T. Shtanko}

Institute of Agriculture of Polissya of National Academy of Sciences of Ukraine

V. Kovaliov, doctor of agricultural sciences

Zhytomyr National Agroecological University

The purpose. To analyze modern state of domestic branch of flax production, to determine problems and perspectives of its further development. Methods. Economic-statistical, analysis and synthesis, monographic and comparative. Results. Modern state of branch of flax production and perspective of its further development in Ukraine is studied. Landmarks of revitalization of the branch are offered, the forecast of economic efficiency of branch of flax production up to 2020 is made. Implementation of the measures directed on competitive development of flax production will enable to increase in the period to 2020 the cultivated areas of flux up to 15 housand hectares, and to reach production of flax fiber in volumes of 11,2 thousand tons at productivity of $7,5 \mathrm{t} /$ hectare. Conclusions. Implementation of landmarks of development of the branch will ensure reaching positive takes in flax production, will promote martempering of the foreign trade balance of Ukraine, augmentation of busy condition and incomes of agricultural population, saving of existing and building of new work stations in agriculture and other sectors of economy, martempering of social situation in country regions.

Key words: branch of flax production, competitive strength, economic efficiency, perspective forecast, revitalization of flax production.

Formulation of the problem. Experts evaluate the functioning of the national branch of flax industry in recent years as critical: the state subsidy has been eliminated, which has led to the loss of flax growing; high price disparity between the cost of inputs (fertilizers, fuel and lubricants, machinery, protective equipment, etc.) and the cost of production (trusts, seeds) in new business and economic conditions (private households) led to loss industry; torn ties between individual links and enterprises of the flax complex; The lack of production in Ukraine of specialized machines required for harvesting and post harvest operations, equipment for the primary processing of flax and the high cost of foreign technology do not contribute to re-equipping the industry with the latest technology. Low efficiency of processing plants now allows to obtain the total weight of flax fiber produced only $25-30 \%$ tipanoho flax and lack Lnokombinat processing of raw materials (flax) on marketable products lonovyrobnykiv forced consumers to seek materials abroad.

At present, the revival and stabilization of the domestic flax industry is due to the introduction of new varieties and the latest energy-saving technologies, increasing yields, improving quality, which will increase the economic efficiency of flax production and processing, and improve the economic relations between market agents.

Methodology of research. The theoretical and methodological basis of the research were the scientific works of the leading Ukrainian scientists on the problems of the functioning and development of the flax industry.

The aim of the study is to conduct a comprehensive analysis of the state, identifying problems and prospects for the development of the national flax industry by 2020. The object of research is the process of competitive development of flax growing up to 2020. The subject of economic research is a set of theoretical, methodological and practical aspects of the functioning and development of the industry of 
flax. In the course of the study a set of methods was used (economic-statistical, analysis and synthesis, monographic and comparison), which allowed to obtain scientifically grounded results.

Research results. Lyon-Dagunets is a traditional culture in the northern and western regions of Ukraine. In particular, specialized areas of cultivation of flax are Polesskiye regions of Volyn, Zhytomyr, Kyiv, Lviv, Rivne, Sumy and Chernihiv regions that have the best climatic conditions for cultivation.

In 1990-1992, the area of sown flax in Ukraine was 162.7 thousand hectares, the gross collection of fiber and seeds - 106.5 and 45.6 thousand tons, respectively, and the yield of fiber was at 9.5 centners per hectare, Seeds $-2.9 \mathrm{c} /$ ha [1].

The record for the flax industry in Ukraine was 1975-1980, when the crop area of this culture amounted to an average of 230-240 thousand hectares, and gross production was at the level of 120 thousand tons of fiber. The level of profitability of the industry amounted to $80-120 \%$, production of flax brought state-owned more than half of the proceeds from all crop production. In addition, domestic flax mills annually exported to the western countries about 10 thousand tons of flax fiber.

By 2008 , farms received state support - compensation of up to $40-45 \%$ of production costs. In addition, there was an effective system of surcharges (from $30 \%$ to $50 \%$ ) of the cost of linoblocks under realization conditions in the corresponding calendar terms, which stimulated the improvement of the quality of raw materials. The profitability of flaxseed production in Ukraine as a whole was at $144-150 \%$, trusts $-30-146 \%$. When fiber yields $4 \mathrm{p} /$ ha and $2 \mathrm{p} /$ ha seed, flax growing in farms has become profitable.

Until 1995, a network of flax plants and flax seed stations (47 flax plants and 21 stations, in Zhytomyr oblast - 11 and 5, respectively) worked in Ukraine. Large linen plants in Zhytomyr and Rivne recycle 100 thousand tons of fiber per year and produce up to 250 million tons of fabrics of various purposes. Kirovograd factory of twisted products, Odessa factory of industrial crops, Kharkov rope factory and many other enterprises worked on flax rails.

In recent years, there are three regions in Ukraine where the flax growing - Zhytomyr, Sumy and Chernigivska - continue to grow in small areas, whose farms together in 2014 gathered flax flax with an area of 1.3 thousand hectares with an average yield of $6.3 \mathrm{c} / \mathrm{Ha}$ (Table 1), [2,3].

1. Dynamics of growing flax (fiber) in $\mathbf{2 0 0 0 - 2 0 1 4}$

\begin{tabular}{|c|c|c|c|c|c|c|}
\hline \multirow{2}{*}{ Indicators } & \multicolumn{6}{|l|}{ Years } \\
\hline & 2000 & 2010 & 2011 & 2012 & 2013 & 2014 \\
\hline \multicolumn{7}{|l|}{ Ukraine } \\
\hline $\begin{array}{l}\text { The collected area, } \\
\text { thousand ha }\end{array}$ & 19.8 & 1.0 & 1.3 & 2.1 & 1.5 & 1.3 \\
\hline Production, thousand tons & 8,3 & 0,4 & 0,8 & 1,8 & 1,1 & 0,9 \\
\hline Productivity, c / ha & 4,2 & 4,0 & 5,9 & 8,6 & 7,3 & 6,3 \\
\hline \multicolumn{7}{|l|}{ Zhytomyr region } \\
\hline $\begin{array}{l}\text { The collected area, } \\
\text { thousand ha }\end{array}$ & 3,6 & 0,0 & 0,4 & 0,7 & 0,6 & 0,3 \\
\hline Production, thousand tons & 1,0 & 0,0 & 0,2 & 0,5 & 0,3 & 0,3 \\
\hline Productivity, c / ha & 2,9 & 0,8 & 5,5 & 7,3 & 5,4 & 9,5 \\
\hline \multicolumn{7}{|l|}{ Sumy region } \\
\hline $\begin{array}{l}\text { The collected area, } \\
\text { thousand ha }\end{array}$ & 1,9 & 0,6 & 0,2 & 0,5 & 0,4 & 0,5 \\
\hline Production, thousand tons & 1,2 & 0,3 & 0,1 & 0,5 & 0,5 & 0,4 \\
\hline Productivity, c / ha & 6,5 & 4,3 & 4,7 & 11,3 & 13,2 & 7,6 \\
\hline \multicolumn{7}{|l|}{ Chernihiv region } \\
\hline $\begin{array}{l}\text { The collected area, } \\
\text { thousand ha }\end{array}$ & 8,5 & 0,3 & 0,6 & 0,9 & 0,5 & 0,5 \\
\hline Production, thousand tons & 3,7 & 0,1 & 0,5 & 0,8 & 0,3 & 0,2 \\
\hline Productivity, c / ha & 4,4 & 4,2 & 6,8 & 8,6 & 5,0 & 3,3 \\
\hline
\end{tabular}


In 2000, in Zhytomyr oblast, flax grown in 17 districts. However, due to the general decline in the flax industry in Ukraine in 2007, crops of flax remained only in the northwestern regions of the region (Baranivskyi, Brusilovsky, Volodarsk-Volynskyi, Emilchinsky, Korostensky, Novohrad-Volynskyi and Ovrutsky), in 2013 - only in Novograd-Volynskyi (520 ha), Volodarsk-Volynskyi (65 ha) districts and a scanty area in Korostensky (4.5 ha) area; in 2014, the areas of flaxen flax cultivation in the oblast decreased to 300 ha $[4,5]$.

Given the situation in flax, a revival is possible with the participation of investors and the support of regional state bodies.

The guidelines for the revival of the industry can be determined based on the volume of financial support, the availability of material and technical resources and solutions in the complex of problems of innovation development of flax by performing the following tasks:

1. Expansion of sown areas of flax due to seed system of high-yielding varieties and introduction of innovative cultivation technologies. Scientific institutes in recent years have derived a number of high-yielding flax varieties, which can contribute to improving the economic efficiency of the industry. In particular, competitive high-yielding varieties of Zhuravka and Nadiya flax have been brought out for the Polissya region of the Polissya Institute of Agriculture. Their seed production is still at the minimum level, but if necessary, the Institute has the opportunity to produce seed of the basic category of these varieties in 2017 on an area of 30-50 hectares, with the yielding of volumes in 2020 (with the participation of seed farms) to 300-500 tons seeds of higher reproductions, that is, on the area of 25004200 hectares. For needs in 2016 LLC "Agrosoyuz" of Novograd-Volynsky region produced 200 tons of seeds and LLC "Tvk Agro" in Volodarsko-Volynskyi region - 100 tons of seeds (only 300 tons of varieties Agate and Magic), which can plant 2500 hectares of land.

2. Provision of farms with material and technical base. As of 01.01 .2014 in the flax farms of the region 298 units of special flax equipment were concentrated, which includes flax combines, flax ribbing rollers, roll balers, driers of flax grouse. Considering that flaxseed and crop maintenance are carried out by general purpose machinery (plows, cultivators, harrows, drills, sprayers, fertilizer spreaders and others), flax production depends mainly on the availability of specialized equipment. The standard minimum of flax equipment is 4 items (flax comb, rotary, roll baler, roller loader) for every 50 hectares. Based on the load requirements for one set and taking into account the depreciation of the existing equipment $(75-80 \%)$, it is possible for this technique to harvest flax from the area of 2500-3000 hectares in 2017-2018 [6].

3. Recycling of produced flax straw on working flax mills. In Zhytomyr region, only 5 of NovogradVolyn, Emilchinsky, Volodarsk-Volynsky, Korostyshevsky and Krasnoarmejsky can operate from 11 flax plants. When working in one shift, they can process 15 thousand tons of trusts, that is, the entire trust, which will be collected from 3000 hectares of flax. Taking into account the fact that the Zhytomyr Flax Plant does not work, further processing of the produced flax fiber can be carried out at the Rovno Flax Plant.

Thus, in 2017, with minimal investment, it is possible to start a revival of the flax industry in the Zhytomyr, historically floating region of the Polissian zone. The linen can be grown in private and small farms, suitable for growing in small villages, where it is possible to place a flax processing plant, thus providing infrastructure and jobs. For the cultivation of flax flax, labor costs are, on average, 4.5 thousand man-years. (550-580 man-days) per 100 hectares.

The mechanism of the industry's exit from the crisis involves a series of measures aimed at technical, scientific, organizational and material provision of agrarian and processing enterprises, and aims at the innovative development of the industry through the implementation of the following tasks: implementation of an effective system of state and regional support for flax production; Creation of a flax seed system taking into account the needs for cultivating varieties and promoting the introduction of highly productive flax varieties; Introduction of innovative technologies in flaxseed; Provision of agricultural producers with specialized equipment for flax harvesting and post-harvest works; Technical re-equipment of enterprises of primary processing of flax; Restoration of the Zhytomyr Flax Factory; Promotion of competitive flax 
market development; scientific, educational and informational support of the branch; protection of the environment; Attraction of investments; The formation of a regional innovation flax cluster.

Implementation of an effective system of state support for flax production. Until 1994, there was a system of state subsidies in Ukraine, accounting for about $45 \%$ of the cost of flax production, which provided a high level of profitability of flax production (up to 150\%). Crisis in the economy and lack of state support have led to the fact that flax production has become unprofitable ().

Therefore, since 1997, flax industry has begun to receive state support in the form of expenditures from the state budget. Until 2004, the State Enterprise "Lionokopopleprom" of the Ministry of Agrarian Policy of Ukraine was the manager of budget funds, through which support was provided only to base farms. All other producers did not receive the flax of state support, which did not stimulate agricultural and processing enterprises to increase production volumes.

In 2004-2006, the state budget funds in support of domestic flax production were provided by the Ministry of Agrarian Policy of Ukraine through the regional departments of the State Treasury to all flax farms per hectare of sowing. This allowed keeping the profitability of flax production at a minimum level.

The sharp rise in prices for fuel, fertilizers, plant protection products, spare parts and other resources in 2005-2006 significantly increased the costs of agricultural producers for flax grown, and the industry was unprofitable without state subsidies.

According to the calculations, taking into account the forecast yield growth, it is possible to ensure the profitability of the industry at the level of $80 \%$ (in comparison with other crops) if the size of subsidies of the State and regional budgets for one hectare of sown flax flax will not be less than 4000 hryvnias.

It is necessary to provide flax farms and enterprises of primary processing of flax with annual subsidies from the State and regional budgets to cover the costs associated with acquiring agricultural machinery and equipment under leasing conditions, as well as to reduce the cost of loans necessary for the reconstruction and technical re-equipment of enterprises.

Creation of seed system of flax. The prospects for the development of flaxseed in Ukraine to a large extent depend on the organization of the system of seed production, which should ensure the organized distribution of high-yielding flax varieties with high spinning properties of fiber and provision of farms with sown material that guarantees high yield and quality flax truss in the agro-climatic conditions of a particular farm.

The productive and qualitative characteristics of the varieties that are in production must be constantly maintained and their seed material multiplied in quantities necessary to meet the needs of commodity farms.

At the same time, it should be noted that in recent years, as a result of the decline of flax, the seed system of flax in Ukraine was completely destroyed. The functions of production of elite seeds were assumed by the research institutes, and in the future varietal replacement and grading began to be of a random nature. At the same time, issues of sorting and sorting are mainly handled by flax makers themselves.

In order to achieve the $100 \%$ supply of flax farms, domestic sowing material needs to significantly increase the production of seeds of the elite and the first reproduction and increase the capacity of purification and seed drilling.

The main prerequisite for the development of flax seed production is the creation of a branched system that would determine the complete need for seeds in the assortment and in categories, guaranteeing the production of these volumes and the high quality of the sowing material.

Implementation of innovative technologies. Capacity building flax industry through the introduction of innovative technologies in agriculture, processing and manufacturing is one of the priorities. Wide involvement of innovations in flaxseed should provide a comprehensive approach to solving the problems of the industry.

Scientific support production of innovative products in flax conducted by leading national scientists in breeding, seed, technology of growing, harvesting and processing. 
In addition, the developed technology for odnotypovoho fiber from trusts flax directly to households, which involves cooking the trusts with the stalks of flax spread out lonokombaynamy, gathering the trusts baling, transporting it to the place of processing and separation from her odnotypovoho fiber unit.

Using this technology will completely mechanize the processes of harvesting and processing of flax straw to fiber.

Processing trusts in odnotypove fiber without division into long and short simplifies the manufacturing process, which will reduce metal and energy equipment and reduce the cost of the resulting fiber.

To ensure the textile enterprises of the state own raw materials, it is necessary to organize the production of cotton-like linen fibers - kotinina. The process kotonizatsiyi short (low-grade) fiber flax is shtapelyuvanni (shortening), cleaning it from Kostrytsia and splitting into elementary fibers. Cotonized flax fiber can be further used in the production of mixed linseed.

The scope of the use of linen short fibers is constantly expanding. In this regard, obtaining short flax fiber with low cost is now an urgent task. The selection of whole fiber in the form of a short one can lead to a simplification of the technology of collection and recycling and a significant reduction of costs. Recently, short fiber flax was widely used in enterprises for processing mixed with other natural and synthetic fibers for the production of advanced composite materials and insulation.

Provision of agricultural producers with specialized equipment. One of the main factors hindering the further increase of flax production is the availability of special equipment to agricultural producers and the level of its deterioration. The features of flax is that for the cultivation and harvesting of this crop, in addition to agricultural machines of general purpose, it is necessary to have a number of special machines. Operations on tillage, fertilization, protection of crops from pests, diseases and weeds are carried out by general purpose vehicles, which are satisfactory in farms and their condition is satisfactory. For the sowing of flax, selection and threshing, rotation of the tapes and trusted, loading and transporting rolls, special machines are also used.

Over the past 10 years, flax farms have practically not purchased new machines, and those that are available in farms are physically worn, partially disassembled and in fact exhaust their technical resources.

Almost the whole complex of machines for flax is developed and manufactured in Russia (Behekselmash, Pskovlemash plants). European companies "Dehont", "Van de Bilt" and others produce high-performance self-propelled flax harvesting machines, but because of their excessively high cost they are virtually inaccessible to Ukrainian flax makers.

In recent years, no enterprise in Ukraine has organized the manufacture of machines and equipment for the harvesting and processing of flax. Only OJSC "Irpinmash" in 2002-2004 started work on the restoration of flax harvesters LK-4A, the manufacture of flax-rotating IIp-1 and the pilot sample of the PML-1 flail-picker, which, unfortunately, is not enough for technical re-equipment of the industry.

In the absence of the proper technique of own production, in the coming years, technical re-equipment of manufacturers of flax production in Ukraine should take place through its procurement in Russia and other countries.

Technical reequipment of enterprises of primary processing of flax. Technological equipment, which nowadays has been provided with enterprises of primary processing of flax, was produced before 1991 and is physically and morally obsolete and does not meet modern production requirements.

The main requirement put forward in the technical re-equipment of flax mills, the use of technological lines for the processing of flax truss with a ratio of output of long and short fibers is not less than $50 \%$ : $50 \%$. Based on the volume of recycled flax straw, the amount of long flax fiber produced should be at least $13,5 \%$.

As noted above, equipment for the flax industry in Ukraine is not manufactured, and the cost of technological lines for the processing of flax roots offered by European producers is virtually unrealistic for Ukrainian flaxseed.

Promoting the development of a competitive flax market. For active market policy, strengthening of market positions and expansion of the product sales segment it is envisaged: to actively search for 
foreign partners - wholesale buyers of flax fiber and other flax products abroad; To conduct an active advertising campaign in the media; To cooperate with embassies, trade representatives, chambers of commerce and industry of different countries of the world; to conduct tenders for determining the best terms of investment, the choice of suppliers of material resources and the best wholesalers of fiber and fabrics in order to increase the efficiency of flax growing and processing; To actively cooperate with commodity and agrarian exchanges in Ukraine and abroad; To oppose the dumping of commodity seed prices in Ukraine.

One of the important and priority directions of market policy should be the establishment of contacts and cooperation with the direct producers of material and technical resources to ensure the technological cycle of growing and processing flax (without the participation of intermediaries), the search for optimal payment conditions for the supplied resources.

It is necessary to actively promote and promote the usefulness of flax products, which will form a domestic demand for these products.

Scientific, educational and informational support foresees the use of scientific potential for information support of the industry, as well as for the development of new and improved functional flax production technologies, introduction of optimal automated control systems for technological processes and production, creation and improvement of the national flax seed system and quality measurement system Raw materials and commodity products, expansion of assortment, improvement of quality of products from flax and reduction Its cost, development of mechanisms for economically beneficial relations between enterprises of the flax complex and consumers, justification of the ratio of volumes of use in the country and the export of domestic flax products.

For the successful accomplishment of tasks it is necessary to organize a system of training and raising the professional level of personnel of the linen industry, for which it is worth coordinating the training of specialists in higher and secondary specialized educational institutions with the need of the region and all parts of the linen complex.

The scientific support of the branch in the region is now carried out by the Institute of Agriculture of the Polissya National Academy of Sciences, which includes: creation and introduction into production of new varieties of flax flax with high yield and quality of fiber, resistance to creeping and disease; Reproduction and reproduction of original and elite flaxseed seeds for the complete supply of varieties and varieties; Development and implementation of separate technology for harvesting seed clove flax flax; Development and improvement of competitive technologies for growing flax flax, which include the use of a new generation of plant protection products and modern equipment, based on new trends in the use of flax products; Approbation and introduction of rolled technology for harvesting and processing of flax straw; Improvement of existing and development of the latest technologies for the processing of flax fiber in relation to areas of its unconventional use; Bookmark of demonstration polygons on propaganda of new varieties, technologies of growing and harvesting flax flax; staff training, meetings, seminars, field days.

The modern level of technological culture involves the development of information support of the manufacturer regarding raw materials, prices, advanced technologies, effective methods for determining the quality of markets, markets, equipment, spare parts, manufacturers of machinery and equipment, legislative and regulatory framework.

Environmental protection. The ecological aspects of flax production are the possibility of using flax crops on lands contaminated as a result of the Chernobyl accident, as well as on lands that have not been cultivated in recent years, in order to maximize their efficient use.

On the other hand, enterprises for the production and use of raw flax necessary to develop and implement sustainable use of technology throughout the range of waste lonovyrobnytstva organize the collection and recycling of environmentally hazardous constituents to develop and implement a means of purification and reduce emissions enterprises. 
Legal, financial and organizational support. For the revival and effective development of flax it is necessary to process and enforce the modern regulations and regulatory documents: state standards, technical specifications, provisions, etc.

It is important to adapt to the conditions of flax production the issue of social protection of workers, to provide an effective system of labor protection management, taking into account the peculiarities of processing enterprises of flax.

The sectoral program for the revival and innovation of flax production in Ukraine for 2017-2020 should be the main document that will define a set of interrelated tasks and measures aimed at solving the most important problems of innovative development of the flax industry. The Program must be financed through consolidation of funds from the State and regional budgets, own sources of enterprises, as well as loans and attracted investments.

Implementation of the main measures for the revival of flax growing in Zhytomyr oblast will allow: to increase tillage area of flax flax till 2020 by 15 thousand hectares; to bring volumes of production of flax fiber in 2020 to 11.2 thousand tons at a yield of $7.5 \mathrm{c} /$ ha (Fig. 1); to ensure annual production of high-flax flax seed at the level of 6 thousand tons starting in 2017; to ensure stability in the work of agricultural enterprises; to preserve existing ones, to restore and create new production facilities for the production of linseed and the production of finished linen products; restore over 1 thousand and create more than 5 thousand new jobs.

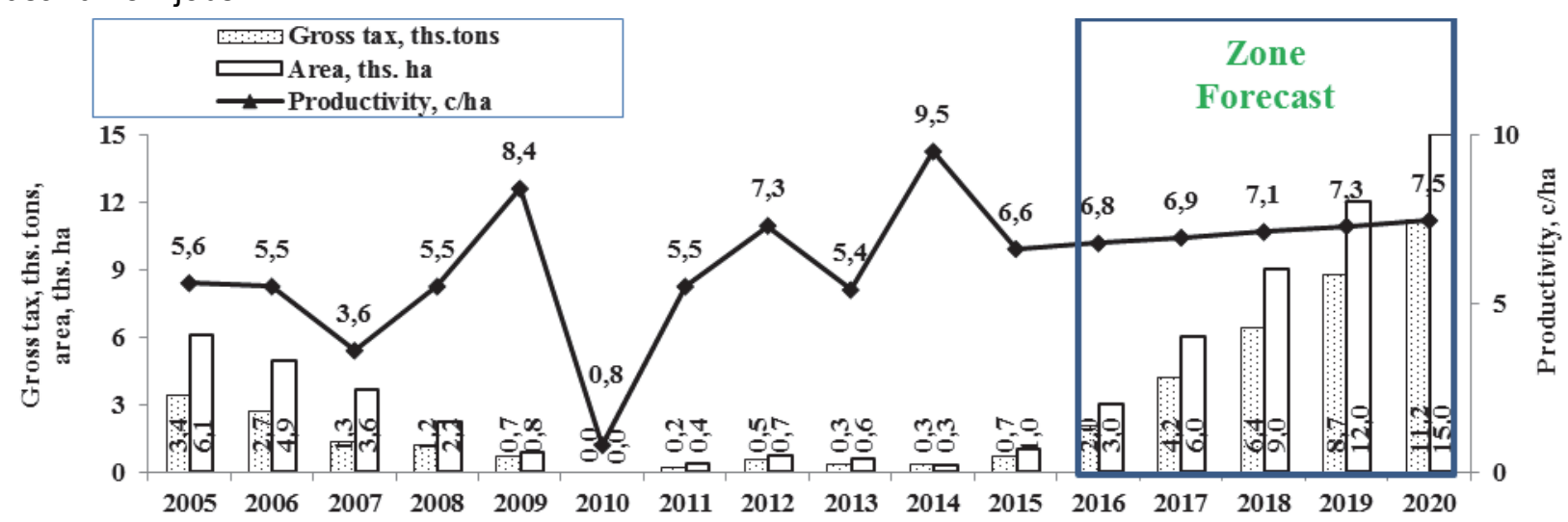

Fig. 1. Dynamics and growth forecast of flax in the Zhytomyr region

Prospective revival of the industry is possible under favorable conditions for the development of flax growing, ensuring a significant increase in the production of competitive flax products, stabilizing agricultural enterprises and improving the socio-economic status of Ukrainian villages, reducing Ukraine's dependence on imports of cotton, wool and natural silk, and increasing the export potential of Ukraine.

\section{Conclusions}

The improvement of the state of the raw material base of the linen industry, its structure, together with the innovative development will ensure the growth of production of not only traditional but also new types of flax products, reducing its cost, which in turn will promote the expansion of the scope of flax as a renewable raw material and will make it possible to reduce volumes of import of raw materials and finished products.

Adoption of the relevant standards for flax and ready-made flax products and their harmonization with international standards will increase the quality of products, its competitiveness on foreign markets and will strengthen the export potential of the state.

In general, the implementation of the landmarks of development will make it possible to achieve positive results in the development of flax growing, will contribute to the improvement of the foreign trade balance of Ukraine and the growth of employment and incomes of the rural population, preservation of existing and creation of new workplaces, both in agriculture and in the processing and industrial sectors 
of the economy, improvement Social situation in the countryside. The development of flax is the basis for creating a reliable raw material base for light, chemical, food, medical and other industries of Ukraine.

Growing flax flax per 100 hectares for the developed flax technology developed by the Institute on the basis of industrial flow roll technology will provide a profit of 1.5 million hryvnias, profitability of production will be $48.6 \%$.

The return on investment and the profitability of production will depend on the owner and on the investment and equipment he is ready to invest in flax production, it is generally 3-5 years.

\section{Bibliography}

1. Ukraine's Crop Production for 2015: Stat. gathering. / [Ed. OHM. Prokopenko]. - Kyiv: State Statistics Service of Ukraine, 2016. - 180 p.

2. Statistical information. State Committee of Statistics of Ukraine [Electronic resource]. - Mode of access: http://www.propozitsiya.com.

3. Agriculture of Ukraine for 2014: Stat. gathering. / [Ed. N.S. Vlasenko]. - Kyiv: State Statistics Service of Ukraine, 2015. - $397 \mathrm{p}$.

4. Harvest of crops, fruits and berries in Zhytomyr region districts in 2009 // Statistical bulletin. Zhytomyr: Main Department of Statistics in Zhytomyr Oblast. - 2009. - $91 \mathrm{p}$

5. Statistical yearbook of Zhytomyr region. The Main Department of Statistics in Zhytomyr Oblast, Zhytomyr. - 2012. - $501 \mathrm{pp}$.

6. Prospects for the development of flax in Zhytomyr / RI Rudik, VB Kovalev, T.Yu. Priyamachuk and others. // Zhitomir: Polissya Institute of Agriculture, National Academy of Sciences, 2015. - 25 p. 